\title{
Detection and Partial Characterization of a Second Closterovirus Associated with Little Cherry Disease, Little cherry virus-2
}

\author{
M. E. Rott and W. Jelkmann
}

Federal Biological Research Center for Agriculture and Forestry, Institute for Plant Protection in Fruit Crops, Schwabenheimer Straße 101, D-69221 Dossenheim, Federal Republic of Germany. Accepted for publication 16 November 2000.

\begin{abstract}
Rott, M. E., and Jelkmann, W. 2001. Detection and partial characterization of a second closterovirus associated with little cherry disease, Little cherry virus-2. Phytopathology 91:261-267.

Little cherry disease (LChD) is a complex and serious viral disease of cherry. Although originally described almost 70 years ago, there has been little progress in identifying the causal agent of the disease due to the difficulty in obtaining purified virus from infected trees. This problem was partially overcome in 1997 when the compete sequence of a closterovirus associated with $\mathrm{LChD}$, Little cherry virus (LChV), was published. This virus could be associated with some, but not all, trees with $\mathrm{LChD}$, indicating that another virus was also involved. We report here the partial characterization of a second closterovirus associated with

two $\mathrm{LChD}$-associated viruses, we refer to $\mathrm{LChV}$ as Little cherry virus-1 (LChV-1). LChV-2 is a new closterovirus with molecular similarities to Grapevine leafroll-associated virus-1 (GLRaV-1) and GLRaV-3 but only distantly related to LChV-1. Based on limited sequence comparisons, $\mathrm{LChV}-2$ is the same virus previously identified in association with $\mathrm{LChD}$ in Canada. In reverse transcription-polymerase chain reaction detection assays using specific oligonucleotide primers to either $\mathrm{LChV}-1$ or $\mathrm{LChV}$ 2, 27 of 28 isolates of LChD tested positive to one or both of these viruses originating from Europe and North America. These results would further confirm the association of $\mathrm{LChV}-2$ with $\mathrm{LChD}$. One isolate, however, tested negative to both LChV-1 and LChV-2, indicating that while this report brings us a step closer to understanding $\mathrm{LChD}$, further work is required to confirm the causal agents of $\mathrm{LChD}$.
\end{abstract} LChD, Little cherry virus-2 (LChV-2), and in order to differentiate the
Little cherry disease (LChD) is a serious problem in both sweet and sour cherry. The first recorded outbreak occurred in the Kootenay valley in British Columbia, Canada, during the early 1930s (16), the probable initial source of the infection originating from infected ornamental cherry trees planted near the commercial cherry orchard. The disease spread quickly, virtually destroying the cherry industry in this area. In subsequent years, it spread to the neighboring Okanagan valley and has since been recorded worldwide $(2,8,22,33)$. Control of LChD in western Canada consists largely of controlling the apple mealybug (Phenacoccus aceris) population, the only known natural vector of $\mathrm{LChD}$ that has been identified in Canada, together with immediate removal of infected trees $(3,11,13,24,41)$. It is forbidden in these two cherry growing areas to import and grow ornamental flowering cherry, many of which appear to be latently infected with LChD (47). In recent years, a serious outbreak of LChD has been recorded in the Altes Land region, near Hamburg in northern Germany $(5-7,20,30)$. The mode of dissemination in this area is unknown because the apple mealybug is an uncommon insect in this region, and thus, unlikely to be the agent responsible for the spread.

Symptoms produced by infected trees consist of small angular and pointed fruit that do not fully ripen and are imperfectly colored. Fruit have reduced sweetness and are unsuitable for consumption. In late summer and fall, leaves show a characteristic red coloration or bronzing of the surfaces (46). Initial studies identified long flexuous virus particles in phloem cells of infected trees,

Corresponding author: M. Rott; E-mail address: mike.rott@urz.uni-heidelberg.de

Publication no. P-2001-0110-01R

(C) 2001 The American Phytopathological Society characteristic of closteroviruses $(37,38)$. The disease is readily graft transmissible to cherry, but all attempts to inoculate it to a herbaceous host have failed (36). In 1996, a closterovirus associated with LChD in Germany was identified and named Little cherry virus (LChV) (26). The complete genomic sequence was determined in 1997 (23). Oligonucleotide primers designed to the LChV genomic sequence were able to amplify the expected sized product from a number of different LChD isolates in reverse transcription-polymerase chain reaction (RT-PCR) assays (44). However, additional isolates of $\mathrm{LChD}$ tested subsequent to these studies consistently tested negative in this assay. Furthermore, initial characterization of a Canadian LChD isolate identified a closterovirus distinct from $\mathrm{LChV}$, suggesting that there are at least two closteroviruses, both of which can cause LChD. Based on these results, we decided to begin characterization of a closterovirus isolated from a cherry tree with $\mathrm{LChD}$ that consistently tested negative in PCR assays using $\mathrm{LChV}$-specific primers. Our aim was to improve the testing procedure for $\mathrm{LChV}$-infected trees, as well as, to better characterize the causal agents of $\mathrm{LChD}$.

\section{MATERIALS AND METHODS}

Virus isolates. Isolates UW2 to UW9, 40/93, 13/93, 37/95, and $119 / 86$ were obtained from orchards at several locations in southern Germany, whereas isolate 120/86 originated from Switzerland and isolate USA6 from the United States. All have been maintained at the Dossenheim Research Station Test Orchard located in Dossenheim, Germany, for several years. Isolate USA6 was imported to Germany in the early 1950s from Davis, CA to be used as a woody indicator for the detection of Prune dwarf virus (PDV) and Prunus necrotic ringspot virus (PNRSV). Only later was it determined that these trees were infected with a virus disease described as K \& S virus (46), which was identical to little cherry based on symptomatology. Isolates AL7-11 were obtained 
from different orchards in the Altes Land region of northern Germany. Isolates UK1/3, UK1/7, UK1/9, and UK1/22 were provided by A. N. Adams (East Malling, U.K.). Isolate Can, originally from Okanagan, Canada, was provided by G. Adam (Hamburg, Germany). Isolates Can L, Can BC, Can NL, and Can TH were provided by D. Thompson (Sidney, Canada). All isolates were indexed positive for leaf symptoms on the woody indicators, cvs. Sam and Canindex (Prunus avium L).

cDNA cloning and analysis. Several nanograms of doublestranded RNA (dsRNA) were extracted, transcribed into cDNA, and cloned essentially as described previously for LChV (26). For RT-PCR cloning, total plant nucleic acid was extracted using a modified silica capture protocol (M. E. Rott and W. Jelkmann, unpublished data) and reverse transcribed with the superscript II enzyme (Life Technologies GmbH, Karlsruhe, Germany) together with one of the primers LCVUSA55L (5'-TCGGGTAAACAGTGAGGGGGACAAAC-3'), LCV2con37L (5'-ATCTCCGACCATCCCGCTTATCTA-3'), or LCV210 (5'-TATCTGACAATTGTGGTAAAGT-3'), as per the manufacturer's instructions. In the latter case, the cDNA was then dATP tailed with terminal deoxynucleotidyl transferase (Life Technologies) according to the manufacturer's suggested conditions. PCR was performed with one of the primer combinations LCVUSA7U (5'ACTGTTACGGGGCGGTCGGAGAATC-3') and LCVUSA55L, LCV2 con26U (5'-CACCCCAACCCTTTTATCTGACAA-3') and LCV2con37L, or BoeoligodT (5'-GACCCACGCGTATCGATGTCGACTTTTTTTTTTTTTTTTV-3') and LCV210, dependent on which primer was used to prime cDNA synthesis. PCR was performed with the Proofsprinter enzyme mix (HybaidAngewandte $\mathrm{GmbH}$, Heidelberg, Germany) under conditions suggested by the manufacturer. Cycling conditions consisted of an initial denaturation step at $94^{\circ} \mathrm{C}$ for $2 \mathrm{~min}$, followed by 35 cycles at $94^{\circ} \mathrm{C}$ for $1 \mathrm{~min}, 59,56$, or $55^{\circ} \mathrm{C}$, (primer combinations LCVUSA7U/LCVUSA55L, LCV2con26U/LCV2con37L, and BoeoligodT/LCV210, respectively) for $1 \mathrm{~min}$, and $68^{\circ} \mathrm{C}$ for $4 \mathrm{~min}$ in a Robocycler (Stratagene, La Jolla, CA). Amplified fragments were gel purified (Qiex II; Stratagene) and ligated into pBS II SK- (Stratagene) that had been previously digested with EcoRV and T-tailed (19). Subclones were generated by digestion with a number of different restriction enzymes with 6-bp recognition sites, followed by gel purification and cloning of the resulting fragments. Sequencing was done with an ABI Prism Sequence Detection System (Applied Biosystems, Foster City, CA). Sequences were assembled and analyzed with the HUSAR computer program (German Cancer Research Center, Heidelberg, Germany). Amino acid sequence alignments were done according to the Lipman-Pearson method (32) or CLUSTAL (21). Phylogenies were derived from the distances between pairs of input sequences as determined by CLUSTAL and application of the unweighted pair group method with arithmetic means algorithm
(42), which guides the alignment of ancestral sequences. The final phylogeny was generated by applying the neighbor-joining method (40) to the distance and alignment data.

RT-PCR detection. For routine PCR detection of both LChV-1 and -2 from total nucleic acid extracted from leaf samples, RT was primed with random hexamers enzyme (Life Technologies $\mathrm{GmbH}$ ) and the LChV-1 3'-end specific primer LCV3EC (5'-GGCACCTTTTATTTTTTATATATGC-3'). For RT-PCR detection of LChV-2, the primers LCV2UP2 (5'-CTCGGCGTATATGGTGGATGTTTA-3') and LCV2LO2 (5'-CCGAATGCAGTGGGGATAGG-3'), which amplify a 438-bp fragment, were selected. Reaction conditions were as follows; $10 \mathrm{mM}$ Tris- $\mathrm{HCl}$ at $\mathrm{pH} 8.8$, $1.5 \mathrm{mM} \mathrm{MgCl} 2,75 \mathrm{mM} \mathrm{KCl}, 2.5 \%$ formamide, $0.2 \mathrm{mM}$ each of dATP, dCTP, dTTP, and dGTP, $0.2 \mu \mathrm{M}$ each primer, $1 \mu \mathrm{l}$ of cDNA, and several units of $T a q$ polymerase (34) in a total reaction volume of $50 \mu \mathrm{l}$. Cycling conditions were as follows; 35 cycles at $94^{\circ} \mathrm{C}$ for $1 \mathrm{~min}, 55^{\circ} \mathrm{C}$ for $1 \mathrm{~min}$, and $72^{\circ} \mathrm{C}$ for $1 \mathrm{~min}$ preceded by an initial incubation at $94^{\circ} \mathrm{C}$ for $2 \mathrm{~min}$, and a final incubation at $72^{\circ} \mathrm{C}$ for $5 \mathrm{~min}$. For detection of $\mathrm{LChV}-1$, primers LCV1U16390 (5'-TCCGCCTGAAGCACCTAATCCA-3') and LCV1L16809 (5'-GGTAAGCGGTATAAAAACCCTCCTCT-3') were selected. PCR conditions were the same as described for the LChV-2 primers, except formamide was not included in the reaction mix.

\section{RESULTS}

Cloning and sequence analysis of LChV-2. Double-stranded RNA extracted from isolate USA6 was used as the template for cDNA synthesis and subsequent cloning. Two cloned cDNAs, LCV55 and LCV7, were partially sequenced. Putative translation products determined from these sequences showed limited similarity to the 1a open reading frame (ORF) translation product from several sequenced closteroviruses. Based on the sequences of LCV55 and LCV7, primers LCVUSA55U and LCVUSA7L, respectively, were synthesized and used to amplify the intervening $\approx 3,200$ base fragment, that was then cloned and sequenced. Additional sequence information was obtained by priming cDNA synthesis with the oligonucleotide LCV210. The synthesized cDNA was tailed with dATP, and the intervening sequences amplified with the primers LCV210 and BoeoligodT by PCR. Analyses of the $\approx 5,900$ nucleotides (Accession no. AF333237) revealed two partial overlapping ORFs. The putative translation products from these two ORFs showed similarities with other closterovirus ORF1a/b predicted translation products. In particular, conserved viral RNA encoded helicase (18) and RNAdependent RNA polymerase (RdRp) (35) motifs could be identified. Within the RdRp polypeptide, a near perfect match $(97.8 \%)$ was detected to an amino acid fragment obtained from a closterovirus associated with a Canadian isolate of $\operatorname{LChD}(11,12)$.

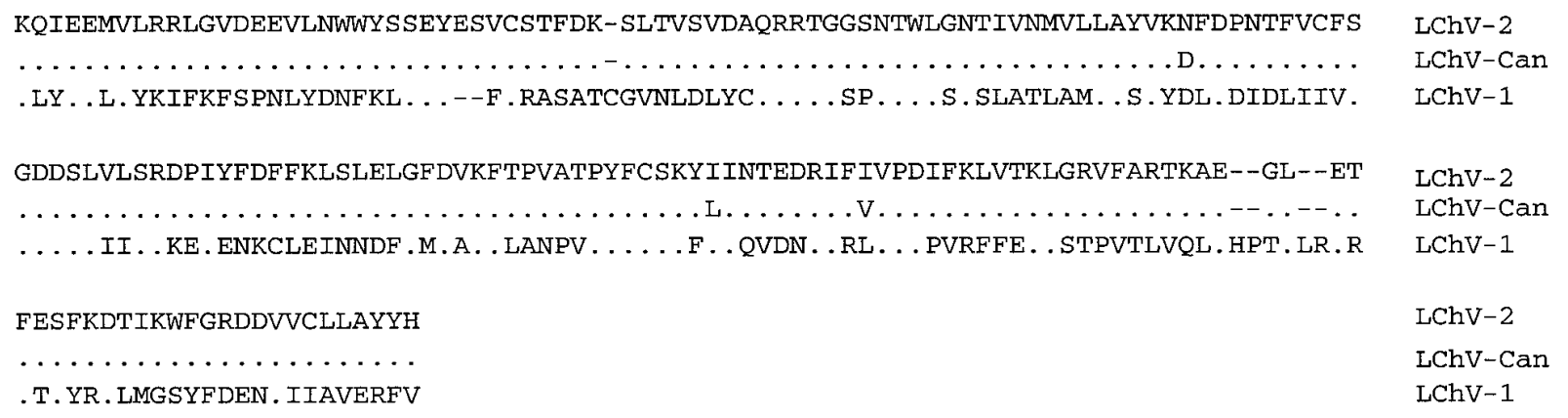

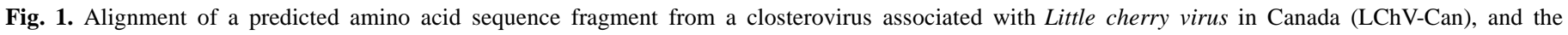

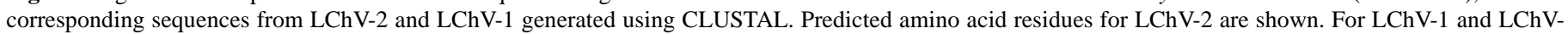
Can, amino acid residues identical with LChV-2 are depicted as periods. Dashes denote spaces introduced to facilitate the alignment. 
An alignment of these sequences, as well as the comparable region from the $\mathrm{LChV}$ genome, is shown in Figure 1. From these results, it is clear that the virus we have partially characterized and the virus associated with the Canadian isolate of LChD are the same and are distinct from LChV. In order to differentiate the two different LChD-associated viruses, we will refer to this as LChV-1, and the new virus as LChV-2.

Figure 2A shows an alignment of the ORF1b-predicted translation products coding for the conserved RdRp motifs from LChV-2, LChV-1, Beet yellows virus (BYV) (1), Lettuce infectious yellows virus (LIYV) (27), Citrus tristeza virus (CTV) (25), and Grapevine leafroll-associated virus-1 (GLRaV-1), GLRaV-2, and GLRaV-3 $(14,31,48)$. Figure 2B shows the phylogenetic relationships between these sequences. Based on these comparisons, LChV-2 is the most divergent. LChV-2 is however, more closely related to GLRaV-1 and GLRaV-3 (37.9 and $41.0 \%$, respectively). Similarities to the other closteroviruses ranged from $22.9 \%$ for LIYV to $33.4 \%$ for BYV. Similarity to LChV-1 was $28.5 \%$.

Figure 3A shows an alignment of the ORF1a-predicted translation products coding for the conserved helicase motifs encoded by LChV-2 and other closteroviruses. A phylogenetic tree from this comparison is shown in Figure 3B. In agreement with the RdRp alignment, the helicase alignment indicates that LChV-2 is most closely related to GLRaV-1 and GLRaV-3 (37.9 and 39.1\%, respectively). Similarity to the other closteroviruses ranged from $25.7 \%$ for CTV to $31.7 \%$ for LIYV. Similarity to LChV-1 was $28.5 \%$

Detection of LChV-1 and LChV-2 by PCR. In previous work by Vitushkina et al. (44), the specific primer pair LCV3EC/ LCVECOI was used in RT-PCR detection assays for LChV-1. Although these primers work well, during the course of this work the primer pair LCV1U16390/LCV1L16809 was developed, and in our hands gave more consistent results due to the higher amplification efficiency of these primers. All isolates that tested positive with the LCV3EC/LCVECOI primer pair were also positive with the LCV1U16390/LCV1L16809 primers (data not shown). As a result, all subsequent tests for $\mathrm{LChV}-1$ were done by the LCV1U16390/LCV1L16809 primer combination. For the detection of LChV-2 by RT-PCR, the primers LCV2UP2/ LCV2LO2 were synthesized. Twenty eight indexed isolates of $\mathrm{LChD}$ were tested with the specific primers to either LChV-1 or LChV-2 (Table 1). The RT-PCR fragments obtained from 22 of these isolates tested with $\mathrm{LChV}-1$ and -2 specific primers are shown in Figure 4. Of the 28 isolates, 27 tested positive to either one or both viruses. Isolates from Germany and Canada tested positive to LChV-1. Isolates from Germany, Canada, the United States, and the United Kingdoms tested positive to LChV-2. Surprisingly, three isolates (37/95, Can L, and Can TH) tested positive to both $\mathrm{LChV}-1$ and -2 . Of the three isolates containing mixed infections, two were from ornamental cherry obtained from Canada, making this the first report of LChV-1 in North America. The third mixed-infected tree, as well as several other trees that tested positive for $\mathrm{LChV}-2$, were of German origin. One isolate $(120 / 86)$ tested negative to both viruses. During the course of this study several additional primer pairs were developed for the detection of $\mathrm{LChV}-1$ or -2 , but none of these could amplify a product from isolate 120/86. Isolate 120/86 displays the characteristic leaf reddening symptoms of LChD and a high $M_{\mathrm{r}}$ dsRNA purified from this isolate was indistinguishable in size to that isolated from either $\mathrm{LChV}-1$ or -2 infected trees (data not shown).

At the Dossenheim Research Station, six trees infected with LChV-2 isolate USA6 and two trees infected with LChV-2 isolate $13 / 93$ have been in the research field plot for over 10 years interspersed with healthy control trees. After this period of time the healthy trees did not become infected with $\mathrm{LChV}-2$ as determined by RT-PCR, nor did they show symptoms of LChD.

\section{DISCUSSION}

Previous work identified the closterovirus LChV-1 in association with LChD in Germany, the sequence of which has been fully determined (23). Here, we report the identification and partial characterization of a second closterovirus associated with $\mathrm{LChD}$, LChV-2. Approximately 5,900 bases corresponding to the LChV-2 genome were cloned and sequenced and code for two partial overlapping ORFs. The predicted translation products from these two ORFs display sequence similarities with the predicted translation products encoded by ORF1a/b from other closteroviruses. In particular, the C-terminal region of the predicted ORF1a translation product encodes amino acid sequences matching conserved motifs present in proteins with RNA helicase activity $(18,29)$. The predicted ORF1b translation product contains highly conserved amino acids common to polypeptides with RdRp activity $(28,35)$. Based on comparisons between the conserved helicase and RdRp domains encoded by LChV-2 with those encoded by several other closteroviruses including $\mathrm{LChV}-1$, it is clear that $\mathrm{LChV}-2$ represents a new distinct closterovirus. Significantly, LChV-2 is the most divergent of the closteroviruses and in particular, only distantly related to $\mathrm{LChV}-1$ although appearing to be most closely related to GLRaV-1 and GLRaV-3. This indicates that LChV-2 is not a divergent derivative of $\mathrm{LChV}-1$ and suggests that the two viruses arose independently in cherry. This is similar to the situation found in grapevine, where the closterovirus GLRaV-2 is more similar to BYV (48), and GLRaV-7 is more closely related to LChV-1 (43). LChV-2, however, is the same virus previously identified in association with LChD in western Canada that devastated the cherry growing industry in this region $(11,12)$. In this region, the causal agent of $\mathrm{LChD}$ can be transmitted by the apple mealybug (Phenacoccus aceris) (36). No known vector has been identified for LChV-1. GLRaV-3 can be transmitted by mealybugs and scale insects $(4,39)$, whereas, GLRaV-1 can be transmitted by scale insects (15). BYV and CTV are both aphid transmissible (9), and the bipartite closteroviruses are transmitted by whiteflies (10). It is interesting to observe that $\mathrm{LChV}-2$ is most closely related to the mealybug/scale insect-transmitted viruses GLRaV-1 and GLRaV-3. LChV-1 on the other hand, groups more closely with the whitefly-transmissible bipartite closteroviruses, whereas the aphid-transmissible closteroviruses group together (Figs. 2B and 3B). This supports earlier work that suggests that LChV-2 associated with LChD in Canada and vectored by the apple mealybug, is the causal agent of the disease in this area. However, no data on the distribution of LChV-1 in the Okanagan and Kootenay valleys are available.

The RT-PCR test for LChV-1 failed to detect this virus in many indexed isolates of $\mathrm{LChD}$, suggesting that another virus is also associated with the disease. All but one isolate of LChD that tested negative for $\mathrm{LChV}-1$, tested positive for $\mathrm{LChV}-2$. Three isolates tested positive for both. These results confirm the association of both viruses with $\mathrm{LChD}$ and suggest that they are causal agents for the disease. That both viruses were found in LChD isolates from Europe and North America also indicates that both are widely disseminated. Because the apple mealybug can transmit LChV-2, this virus is of particular concern wherever this insect vector is present. In the Altes Land region of Germany, rapid spread of LChD has been observed over the last several years $(5-7,20,30)$, and our results show that $\mathrm{LChV}-2$ is present. However, only infrequent samples of the apple mealybug have been found and it is unlikely to be responsible for the rapid spread of $\mathrm{LChD}$ in this region (A. Eppler, personal communication). It remains to be determined if other mealybugs, scale insects, or other insects can be a vector for the disease. It is, however, interesting to observe that two isolates of LChV-2 (USA6 and 13/93) that have been maintained in test fields at the Dossenheim Research Station for over 10 years have not spread to neighboring healthy control trees. Between each group of two 


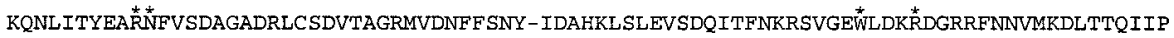
QE . .YS . . S . . YNFTVCERF SGPOEFGOA . AMYMLERS-F . LE.VAKVR . V . AITEKG . RT . MS . . EPSOLRALSS . OKPLNL QE. .LS..S . YYNFIKTERFVGPSEFGRA. AAAVIERC-FKMEEMAKIRC . I. SLTEANILK . . . . TPCQIKA. HGE . KLPFSV QE . .YSF . . . . YNFSTCDRNTSASMFGEA. AM. CLRRC-F. LDAF. SLRD.V.SITRSGIEQ . . E . . TPSQIKAL . . VESPLEI .C. .V.F.N. . .NA . R. CNVG.D.SV. HELKEI . . EEV-VNKAR. AEVTESHLSS . TMLLSD . . . . APNAYKSLLKRA.GSFVFH .C. V.F.S . . NA.R.C.VSSDP.A.AELASL. .NTW-V.GS. AASC.G.T.SQ.AVAASS ...S. SSMAKQSLWVR.RSFVYD ..VILSLSK . . AAPRLNEDISI . E. .N.LLTSLMRCM--EPSR. AE-YF. VVEPDVNKINS . LT . .R. KYG . . LRGFDGN-DW .VIQSLSH . . NAPIINHK . DVKRS.QILY.SVVKSLRFTQDR. TE-WYEP . LPDLFKI . K . . D . . SKYRMLNRR. DFA-SI

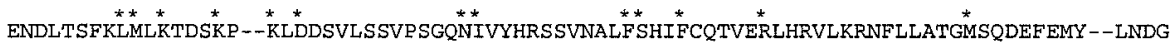

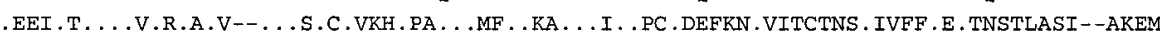

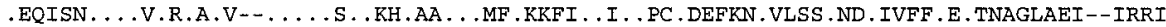

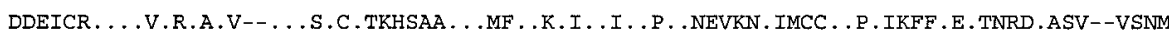

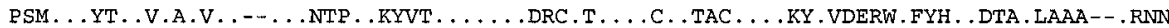

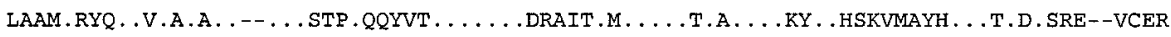

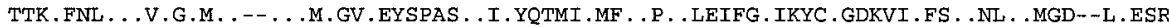
ADKFKTLN. . V.GET . .FT . M. I . TYD. YNAPA . . . YQQI . LY . . . . LECFA . .TYC. SDKIV. YS . . NT . VLAEFTLIESK

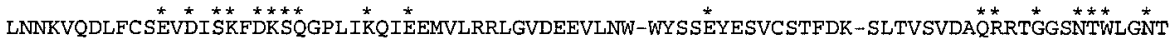

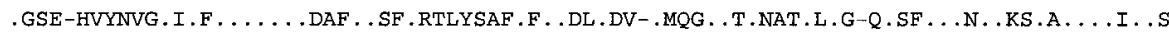

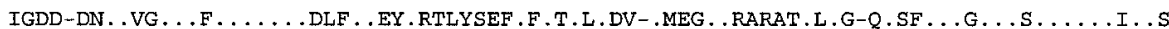
. GDD-DVYHIG . . . . . Y . . . DAFV . AF . VMYYKE . . . . . L . AI- . MCG . RL . IAN . L . G-Q. SFTIEN . KS . A . . . I . . S

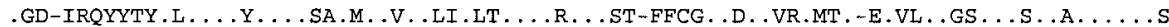

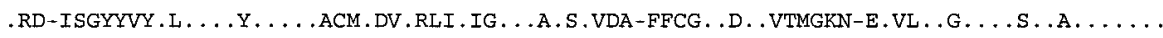

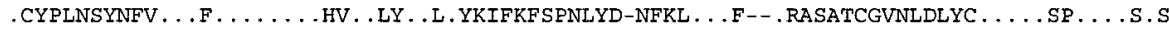
. PLGLNAYHTL . I. F . . . . . . . TCF . LY . . MYKMF . FSP . LYDRDFKYT . . FFT . RAKATCGVDLELGT . . . SP . . . S . .

CTV

CTV

CTV

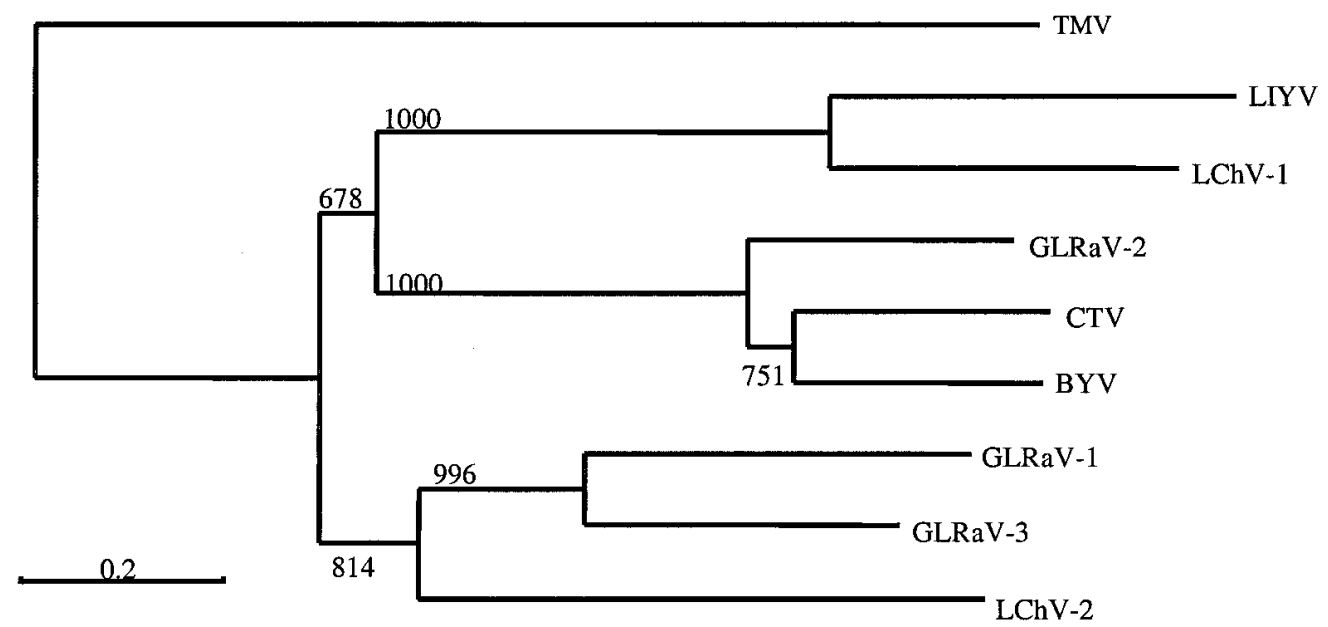

Fig. 2. A, Alignment of the conserved POL motif containing sequences encoded by Little cherry virus-2 (LChV-2) and the closteroviruses LChV-1, Citrus tristeza virus (CTV), Beet yellows virus (BYV), Lettuce infectious yellows virus (LIYV), and Grapevine leafroll-associated virus-1 (GLRaV-1), GLRaV-2, and GLRaV-3 generated using CLUSTAL. The amino acid sequence of LChV-2 is shown. Residues identical to the LChV-2 sequence in the other closterovirus sequences are indicated by a period. Dashes denote spaces introduced to facilitate the alignment. Asterisks above the alignment indicate amino acid residues conserved among all eight viral sequences. B, Dendogram showing relationships between the different closteroviruses based on alignments in A with the addition of Tobacco mosaic virus (TMV) POL motif containing sequences as the nonclosterovirus outgroup. The length of each branch represents the distance between sequence pairs with a bar scale shown below the dendogram. Bootstrap values based on 1,000 trials are shown at each branch point. 


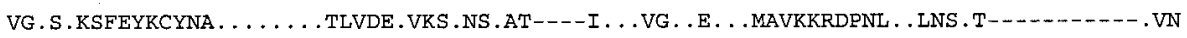
.TFTNLSANVL . YEA . . . . . TLIKV. CETFSK--VNSL . . . . KS. REE . LAKV.RIVLD- . DTPLQTRDR-----IL . . .VFTN. SVD.I. YEA . . . . . TLIDS . LKVFKKGEVSTM . . . KS .QVE.LKKVEKEVSNI . CQKRKDKRSPKKS--IY . .

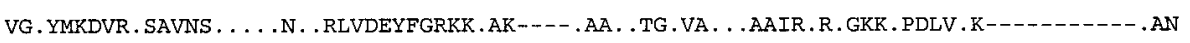
IIDSDRL . TMKIVNK . . S . . . QISQMMFDCHI . GKT-CLA . STKVGKNELIEK . K-NLIVGAKPKNVK---------.V. GLRaV-1 LTFTN. EHSLIVYEA . . . . . HSLVKY . ADYCTK--VSCLVV . . KN. QAE. SQRISRELMD---RKMLAKHVVKTAGRVF . V. MVR. PDVNGLKFYNK . . A . . . TIAKLMSK-DLKNKVKCLA . SYTKVGR. ELIDK . K-KDGIEKPEK.VK--_...... Y. LChV-1 CTV LIYV

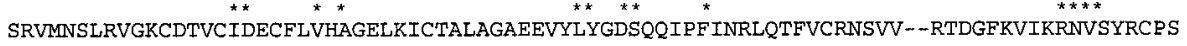
...V.FIVR.MYKR.LV . VHMM.Q.L.QLGVFAT . S.GLFF . IN . . . . EKV.RMDCA.F--VPKKES.VYTSK. . . L .YL . . -N. GLT . KVLYL . . . M. . . AAVA. IEFTKCDSAI . F . . R. . HY . D. NELDTAVL . DLNRFV. DESRVYGE . . . . W AYL.H-H.GCDA.VLF . . . . M . . . SVLA. IEFTRCHK.MIF . . R . HY. E. NELDK. LYGDLDRFV. LQCRVYG . I . . . W .W. I . HPRPNSHVGL . . VYML.K.MFQLTVVSM.VK. .IA . . KN . . . . .EK . . TP.EA.--EFAEEQIDYTDI . . . A AFN.HGKKAI-V.ELYV . . YMS . S. AILMALSNVDFTNCKFF . EN . . YSV . TG. EALFATT--VFKYCH . THDSI . . . . A .YL . . -HIRL. T. LLFV . . .M. . . AIGAVVEFTSCKA.VFF . . R. . HY . H.NDFG. SLLHDIDAFIEPQHR. YGE . . . .W .FL . .NDNILEIVNLYC . . V.MM . . HFLTLLTKIAYQNG. C . . VN . . . . . . DPYTPAYL . RE--FFRKQDLNYDTYT . . . L

\section{B}

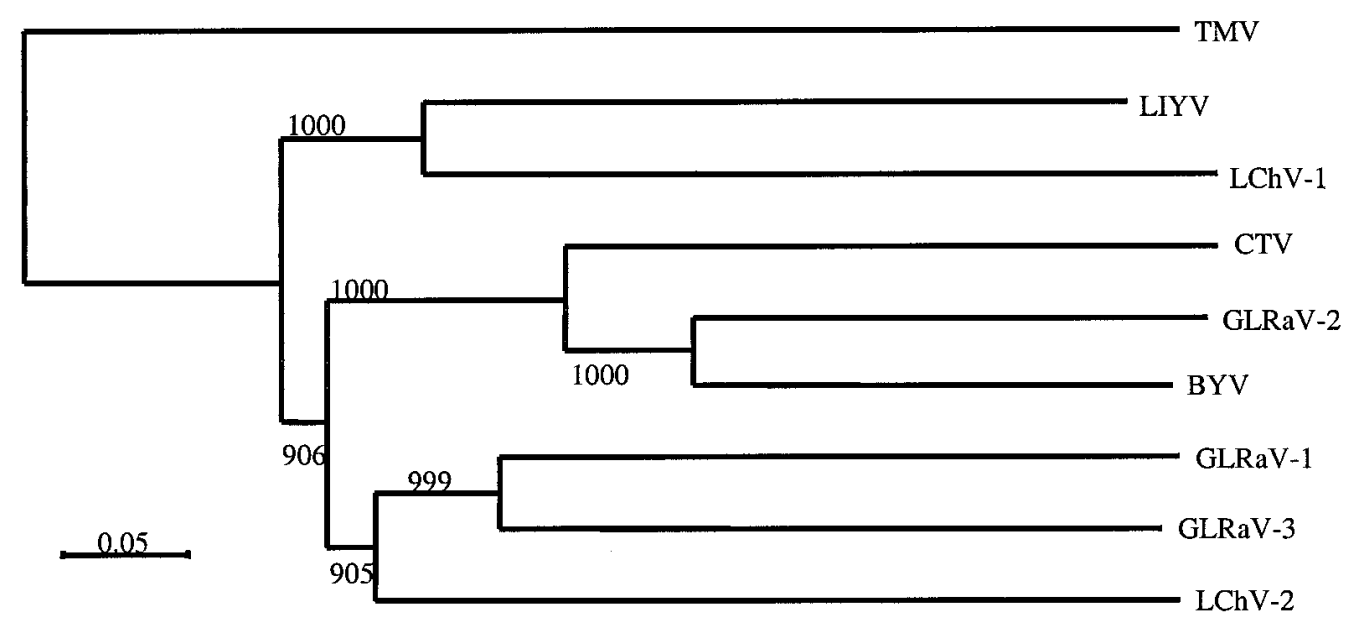

Fig. 3. A, Alignment of the conserved HEL motif containing sequences encoded by Little cherry virus-2 (LChV-2) and the closteroviruses LChV-1, Citrus tristeza virus (CTV), Beet yellows virus (BYV), Lettuce infectious yellows virus (LIYV), Grapevine leafroll-associated virus-1 (GLRaV-1), GLRaV-2, and GLRaV-3 generated by CLUSTAL. The amino acid sequence of LChV-2 is shown. Residues identical to the LChV-2 sequence in the other closterovirus sequences are indicated by a period. Dashes denote spaces introduced to facilitate the alignment. Asterisks above the alignment indicate amino acid residues conserved among all eight viral sequences. B, Dendogram showing relationships between the different closteroviruses based on alignments in A with the addition of Tobacco mosaic virus (TMV) HEL motif containing sequences as the nonclosterovirus outgroup. The length of each branch represents the distance between sequence pairs with a bar scale shown below the dendogram. Bootstrap values based on 1,000 trials are shown at each branch point. 
infected trees, are two healthy control trees that test negative in RT-PCR assays for LChV-2, and have never displayed characteristic LChD symptoms. The Dossenheim test field near Heidelberg is located in the northern part of Baden-Württemberg, approximately $450 \mathrm{~km}$ south of the Altes Land region. If an insect vector present in the Altes Land causes the rapid spread of LChD due to LChV-2, then it would appear that this insect is not common in all parts of Germany. Comparing the situation in the Altes Land region to that in western Canada where LChD spread rapidly and

TABLE 1. Little cherry disease isolates tested in reverse transcription-polymerase chain reaction assays using oligonucleotide primers specific to either Little cherry virus-1 (LChV-1) or Little cherry virus-2 (LChV-2)

\begin{tabular}{|c|c|c|}
\hline Isolate & LChV-1 & LChV-2 \\
\hline UW2 & + & - \\
\hline UW3 & + & - \\
\hline UW4 & + & - \\
\hline UW5 & + & - \\
\hline UW6 & + & - \\
\hline UW7 & + & - \\
\hline UW8 & + & - \\
\hline UW9 & + & - \\
\hline $40 / 93$ & + & - \\
\hline $13 / 93$ & - & + \\
\hline AL7 & - & + \\
\hline AL8 & - & + \\
\hline AL9 & - & + \\
\hline AL10 & - & + \\
\hline AL11 & - & + \\
\hline UK1/3 & - & + \\
\hline UK1/7 & - & + \\
\hline UK1/9 & - & + \\
\hline UK1/22 & - & + \\
\hline USA6 & - & + \\
\hline Can & - & + \\
\hline $37 / 95$ & + & + \\
\hline Can L & + & + \\
\hline Can BC & - & + \\
\hline Can NL & - & + \\
\hline Can TH & + & + \\
\hline $119 / 86$ & - & + \\
\hline $120 / 86$ & - & - \\
\hline
\end{tabular}

uncontrollably via the apple mealybug, it is of critical importance to understand how the disease is being spread in the Altes Land to prevent an outcome similar to what occurred in Canada.

One isolate of LChD (120/86) tested negative to both LChV-1 and -2 . From dsRNA analysis, it could be confirmed that this isolate was infected with a closterovirus-like agent. In addition, this isolate is mixed infected with Cherry necrotic rusty mottle virus (CNRMV), Cherry virus A (CVA), and PNRSV. Several explanations for these results are possible (1). This isolate could represent a divergent sequence variant related to either LChV-1 or LChV-2 that could not be detected in our RT-PCR assays. However, not only the two primer combinations presented here, but also several other primer combinations that we tested during the course of this study failed to detect this isolate (3). It is possible that the symptoms observed are not caused by the closterovirus but due to the combined infection of CNRMV, CVA, and PNRSV (2). It is possible that a third closterovirus is associated with LChD.

That more than one closterovirus can cause similar disease symptoms in the same host plant has been previously documented in grapevine. Extensive work with grapevine leafroll since 1984 has identified seven different leafroll-associated closteroviruses of grapevine (GLRaV-1 to -7) with similar symptomatology (45). Serological testing has conclusively demonstrated that GLRaV-1, GLRaV-3, and GLRaV-7 are causal agents of leafroll disease (17), although Koch's postulates has not been fullfilled. Gross comparisons between woody indicators, cvs. Sam and Canindex (Prunus avium $\mathrm{L}$ ) infected with LChV-1 and LChV-2, do not show strongly differing symptoms (data not shown), however more controlled experiments are required to confirm this. As for $\mathrm{LChD}$, the characterization of the causal agents of grapevine leafroll disease has been hampered by the poor success in transmitting these viruses to a herbaceous host to obtain biologically pure isolates for study. Presently, all attempts to transfer LChV-1 or LChV-2 to a herbaceous host via mechanical inoculation, grafting, or dodder have failed (M. E. Rott and W. Jelkmann, unpublished data). However, what is currently needed is a more extensive survey of trees with LChD using the PCR detection primers presented here in order obtain more evidence for the association of LChV-1 and LChV-2 with the disease.

LChV-1
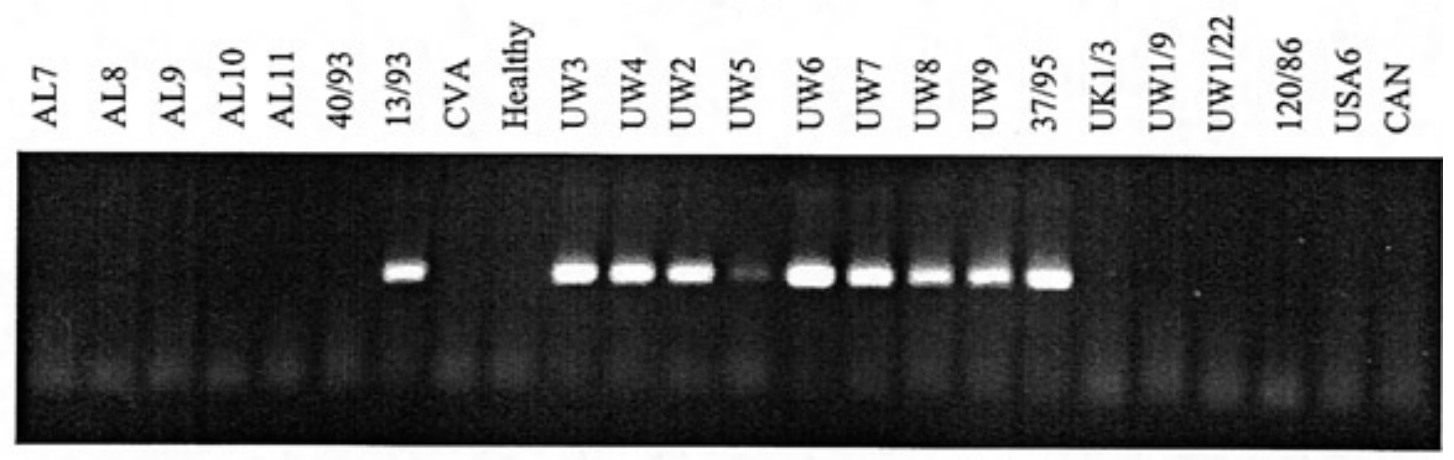

LChV-2

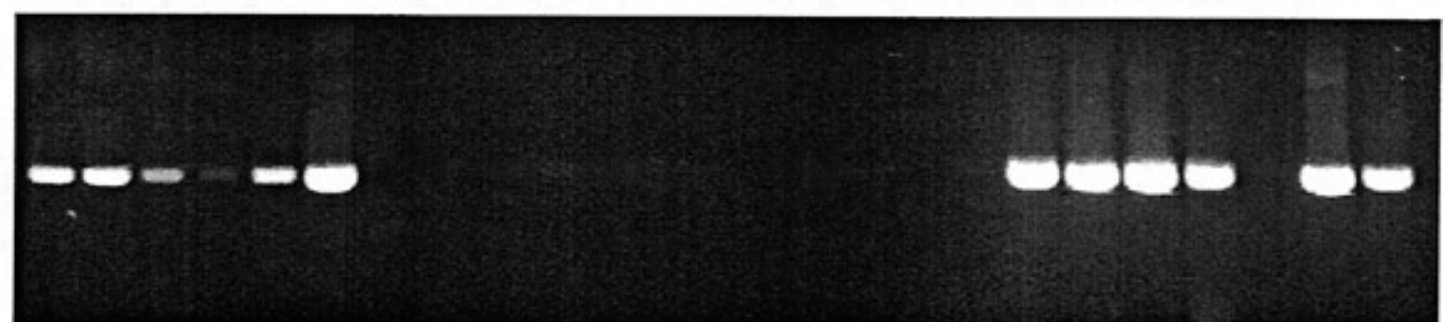

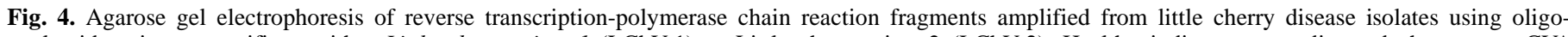

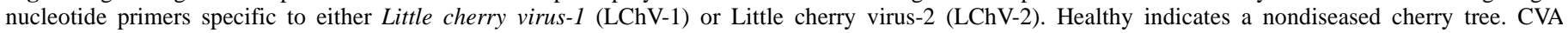
indicates Cherry virus $A$. 


\section{ACKNOWLEDGMENTS} 3889

\section{LITERATURE CITED}

1. Agranovsky, A. A., Koonin, E. V., Boyko, V. P., Maiss, E., Frotschl, R., Lunina, N. A., and Atabekov, J. G. 1994. Beet yellows closterovirus: Complete genome structure and identification of a leader papain-like thiol protease. Virology 198:311-324.

2. Anonymous. 1992. Cherry little cherry disease. Pages 888-892 in: Quarantine Pests for Europe. H. G. Smith, D. G. McNamara, P. R. Scott, and K. M. Harris, eds. CAB International, Wallingford, U.K.

3. Anonymous. 1998. Little Cherry Disease in British Columbia Ministry of Agriculture, Food and Fisheries, British Columbia Government.

4. Belli, G., Fortusini, A., Casati, L., Belli, L., Bianco, P. A., and Prati, S. 1994. Transmission of a grapevine leafroll-associated closterovirus by the scale insect Pulvinaria vitis. Rivista di Patologia Vegetale 4:105-108.

5. Büttner, C., Jelkmann, W., and Graf, H. 1994. Zum Auftreten der Kleinfrüchtigkeit der Süßkirche (little cherry disease) in Erwerbsobstanlagen. Erwerbs-Obstbau 1:10-13.

6. Büttner, C., Wigger, E. A., Zahn, V., and Graf, H. 1992. Das Krankheitsbild der Kleinfrüchtigkeit bei der Süßkirsche. Mitteilungen des Obstbauversuchsringes des Alten Landes 47:320-324.

7. Büttner, C., Zahn, V., Jelkmann, W., and Graf, H. 1993. Die Kleinfrüchtigkeit der Süßkirsche - eine gefürchtete Virose im norddeutschen Steinobstbau. Mitteilungen des Obstbauversuchsringes des Alten Landes 9:345-359

8. Desvignes, J. C. 1999. Little Cherry. Page 94 in: Virus Disease of Fruit Trees. Ctifl, Paris.

9. Dolja, V., Karasev, A. V., and Koonin, E. V. 1994. Molecular biology and evolution of closteroviruses: Sophisticated build-up of large RNA genomes. Annu. Rev. Phytopathol. 32:261-268.

10. Duffus, J. E., Larsen, R. C., and Liu, H. Y. 1986. Lettuce infectious yellows virus-A new type of whitefly-transmitted virus. Phytopathology 76:97-100.

11. Eastwell, K. C. 1997. Little cherry disease-in perspective. Pages 143151 in: Filamentous Viruses of Woody Plants. P. L. Monette, ed. Research Signpost, Triandrum, India.

12. Eastwell, K. C., and Bernardy, M. G. 2001. Partial characterization of a closterovirus associated with apple mealybug-transmitted little cherry disease in North America. Phytopathology 91:268-273.

13. Eastwell, K. C., and Li, T. S. C. 1994. Status of the little cherry disease eradication program in the Kootenay valley of British Columbia. Can. Plant Dis. Surv. 74:115-116.

14. Fazeli, C. F., and Rezaian, M. A. 2000. Nucleotide sequence and organization of ten open reading frames in the genome of Grapevine leafrollassociated virus 1 and identification of three subgenomic RNAs. J. Gen. Virol. 81:605-615.

15. Fortusini, A., Scattini, G., Prati, S., Cinquanta, S., and Belli, G. 1997. Transmission of grapevine leafroll virus 1 (GLRV-1) and grapevine virus A (GVA) by scale insects. Meeting of the International Council for the Study of Viruses and Virus Diseases of the Grapevine, 12th. Lisbon.

16. Foster, W. R., and Lott, T. B. 1947. 'Little Cherry', a virus disease. Sci. Agric. 27:1-5.

17. Garau, R., Padilla, V., Rumbos, I., Walter, B., and Savino, V. 1997. Indexing for the identification of virus and virus-like diseases of the grapevine. Pages 97-117 in: Sanitary Selection of the Grapevine: Protocols for the Detection of Viruses and Virus-Like Diseases. B. Walter, ed. Institut National de la Recherch Agronomique, Colmar.

18. Gorbalenya, A. E., Koonin, E. V., Donchenko, A. P., and Blinov, V. M. 1989. Two related superfamilies of putative helicases involved in replication, recombination, repair and expression of DNA and RNA genomes. Nucleic Acids Res. 17:4713-4730.

19. Hadjeb, N., and Berkowitz, G. A. 1996. Preparation of T-over-hang vectors with high PCR product cloning efficiency. Biotechnology 20:20-22.

20. Harms, M., Büttner, C., Graf, H., and Schickedanz, F. 1996. Untersuchungen zur Ausbreitung der virösen Kleinfrüchtigkeit der Süßkirsche (little cherry disease) in norddeutschen Erwerbsobstanlagen. Erwerbs-Obstbau 1:2-7.

21. Higgins, D. G., and Sharp, P. M. 1989. Fast and sensitive multiple sequence alignments on a microcomputer. CABIOS 5:151-153.

22. Jelkmann, W. 1994. Little cherry disease. In: Technical Guidelines for the Safe Movement of Germ Plasma. M. Diekmann, ed. Food and Agriculture Organization of the United Nations, Rome.

23. Jelkmann, W., Fechtner, B., and Agranovsky, A. A. 1997. Complete genome structure and phylogenetic analysis of little cherry virus, a mealybug-transmissible closterovirus. J. Gen. Virol. 78:2067-2071.

24. Jesperson, G. P., and Carter, G. 1994. Little cherry virus survey in the Okanagan Valley of British Columbia. Can. Plant Dis. Sur. 74:117.

25. Karasev, A. V., Boyko, V. P., Gowda, S., Nikolaeva, O. V., Hilf, M. E., Koonin, E. V., Niblett, C. L., Cline, K., Gumpf, D. J., Lee, R. F., Garnsey, S. M., Lewandowski, D. J., and Dawson, W. O. 1995. Complete sequence of the citrus tristeza virus RNA genome. Virology 208:511-520.

26. Keim-Konrad, R., and Jelkmann, W. 1996. Genome analysis of the 3'terminal part of the little cherry disease associated dsRNA reveals a monopartite clostero-like virus. Arch. Virol. 141:1437-1451.

27. Klaassen, V. A., Boeshore, M. L., Koonin, E. V., Tian, T. Y., and Falk, B. W. 1995. Genome structure and phylogenetic analysis of lettuce infectious yellows virus, a whitefly-transmitted, bipartite closterovirus. Virology 208:99-110.

28. Koonin, E. V. 1991. The phylogeny of RNA-dependent RNA polymerases of positive-strand RNA viruses. J. Gen. Virol. 72:2197-2206.

29. Koonin, E. V., and Dolja, V. V. 1993. Evolution and taxonomy of positive-strand RNA viruses: Implications of comparative analysis of amino acid sequences. Crit. Rev. Biochem. Mol. Biol. 28:375-430.

30. Lakotta, B. 2000. Virenalarm im Alten Land. Der Spiegel 17:228-229.

31. Ling, K. S., Zhu, H. Y., Drong, R. F., Slightom, J. L., McFerson, J. R., and Gonsalves, D. 1998. Nucleotide sequence of the 3 '-terminal twothirds of the grapevine leafroll-associated virus-3 genome reveals a typical monopartite closterovirus. J. Gen. Virol. 79:1299-1307.

32. Lipman, D. J., and Pearson, W. R. 1985. Rapid and sensitive protein similarity searches. Science 227:1435-1441.

33. Nemeth, M. 1986. Cherry little cherry. Pages 292-296 in: Virus, Mycoplasma, and Rickettsia Diseases of Fruit Trees. M. Nemeth, ed. Martinus Nijhoff Publishing, Dordrecht, Netherlands.

34. Pluthero, F. G. 1993. Rapid purification of high-activity Taq DNA polymerase. Nucleic Acids Res. 21:4850-4851.

35. Poch, O., Sauvaget, I., Delarue, M., and Tordo, N. 1989. Identification of four conserved motifs among the RNA-dependent polymerase encoding elements. Eur. Mol. Biol. Organ. J. 8:3867-3874.

36. Raine, J., McMullen, R. D., and Forbes, R. D. 1986. Transmission of the agent causing little cherry disease be the apple mealybug Phenacoccus aceris and the dodder Cuscuta lupuliformis. Can. J. Plant Pathol. 8:6-11.

37. Raine, J., Weintraub, M., and Schroeder, B. 1975. Flexuous rods and vesicles in leaf and petiole phloem of little-cherry diseased Prunus spp. Phytopathology 65:1181-1186.

38. Raine, J., Weintraub, M., and Schroeder, B. 1979. Hexagonal tubules in phloem cells of little cherry-infected trees. J. Ultrastruct. Res. 67:109-116.

39. Rosciglione, B., and Gugerli, P. 1989. Transmission of grapevine leafroll disease and an associated closterovirus to healthy grapevine by the mealybug Planococcus ficus. (Abstr.) Phytoparasitica 17:63.

40. Saitou, N., and Nei, M. 1987. The neighbor joining method: A new method for reconstructing phylogenetic trees. Mol. Biol. Evol. 4:406-425.

41. Slykhuis, S. T., Yorston, J., Raine, J., McMullen, R. D., and Lis, T. S. C. 1980. Current status of little cherry disease in British Columbia. Can. Plant Dis. Sur. 60:37-42

42. Sneath, P. H. A., and Sokal, R. R. 1973. Numerical Taxonomy-The Principles and Practice of Numerical Taxonomy. W. H. Freeman \& Co., San Francisco.

43. Turturo, C., Rott, M. E., Minafra, A., Saldarelli, P., Jelkmann, W., and Martelli, G. P. 2000. Partial molecular characterization and RT-PCR detection of grapevine leafroll-associated virus 7. International Council for the Study of Viruses and Virus Diseases of the Grapevine, 13th. Adelaide, South Australia.

44. Vitushkina, M., Fechtner, B., Agranovsky, A., and Jelkmann, W. 1997. Development of an RT-PCR for the detection of little cherry virus and characterization of some isolates occurring in Europe. Eur. J. Plant Pathol. 103:803-808.

45. Walter, B., and Martelli, G. P. 1997. Clonal and sanitary selection of the grapevine. Pages 43-95 in: Sanitary Selection of the Grapevine: Protocols for the Detection of Viruses and Virus-Like Diseases. B. Walter, ed. Institut National de la Recherche Agronomique, Colmar.

46. Welsh, M. F., and Cheney, P. W. 1976. Little cherry. Pages 231-237 in: Virus Diseases and Noninfectious Disorders of Stone Fruits in North America. R. M. Gilmer, J. D. Moore, G. Nyland, M. F. Welsh, and T. S. Pine, eds. Agric. Res. Serv., Washington D.C.

47. Wilks, J. M., and Reeves, E. L. 1960. Flowering cherry, a reservoir of the little cherry virus. Phytopathology 50:188-190.

48. Zhu, H. Y., Ling, K. S., Goszczynski, D. E., McFerson, J. R., and Gonsalves, D. 1998. Nucleotide sequence and genome organization of grapevine leafroll-associated virus-2 are similar to beet yellows virus, the closterovirus type member. J. Gen. Virol. 79:1289-1298. 